Copyright (C) 2018 by Academic Publishing House Researcher

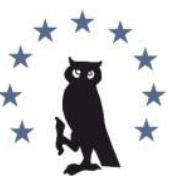

Published in the Russian Federation

European Researcher. Series A

Has been issued since 2010.

ISSN 2219-8229

E-ISSN 2224-0136

2018, 9(2): 153-162

DOI: 10.13187/er.2018.2.153

www.erjournal.ru

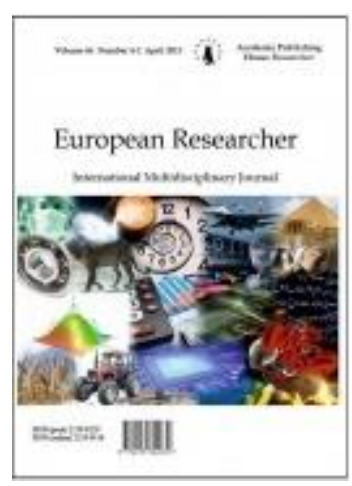

\title{
Hermeneutic Analysis of Russian 21st Century Feature Films on the University Topic
}

\author{
Roman Salny a \\ a Rostov State University of Economics, Russian Federation
}

\begin{abstract}
The article provides a hermeneutic analysis of Russian feature films 21st century about students, the analysis of the experts' views, of the ideological and sociocultural context of 20002017. According to the results of the study, it can be concluded that in the Russian 21st century films about students have the following characteristics: the characters of the students became very similar to each other and interchangeable, but the differentiation in the social financial situation of students is noticeable; students do not formulate any life goals, do not ask questions about the meaning of their actions, etc.; they are indifferent to moral problems and standards (traditional "eternal" values for the Soviet cinema: loyalty, self-sacrifice, love, hard work remained in the past); students often show familiarity (including corruption) in relations with teachers. The main genre of films about university is comedy with a significant number of obscene episodes, including sex, rude expressions, etc.

Keywords: hermeneutic analysis, feature film, TV series, Russia, students, teachers, $21^{\text {st }}$ century, university, cinema.

\section{1. Введение}

В XXI веке число российских фильмов на тему вуза стало заметно увеличиваться, причем в основном в развлекательном телеформате, что в итоге привело к резкому снижению художественного уровня такого рода продукции.

Если в советских фильмах о студентах комсомольцы-отличники пытались образумить и наставить на истинный путь лодырей и бездельников, то в XXI веке ситуация изменилась на противоположенную - жизнерадостные, беззаботные и отстающие в учебе юные персонажи пытаются переманить на свою сторону «зубрил» и «ботаников». Теперь чтобы экранному студенту не отличаться «от всех» ему необходимо уметь развлекаться, успевать за модой, прогуливать лекции и т.п. (по мнению создателей такого рода медиатекстов и владельцев телеканалов, это, видимо, должно привлечь к ним малообразованную аудиторию, ориентированную на развлекательные функции кинозрелища).
\end{abstract}

\section{2. Материалы и методы исследования}

Материал исследования - фильмы и телесериалы о студентах, снятые в период с 2000го по 2017-й год. Нами используется метод сравнительного герменевтического анализа (Эко, 2005; Бэзэлгэт, 1995; Silverblatt, 2001), который, на наш взгляд, особенно важен для медиаобразовательных задач при обучении будущих историков, культурологов, искусствоведов, социологов, филологов, теологов, психологов, педагогов. 


\section{3. Обсуждение}

Многие фильмы последних двух десятилетий создаются преимущественно для молодежной аудитории, так как в кинематограф сегодня существует как часть культуры молодых, где молодежь - основная движущая сила массового потребления (Ятина, Калинина, 2011: 170). Следуя ее интересам, авторы все чаще выбирают в качестве главных персонажей студентов, с которыми юные зрители легко себя идентифицируют. В современных фильмах о студентах практически не показывается процесс обучения. По мнению одного из исследователей, содержание современных молодежных сериалов «не очень тесно связано с современной российской студенческой жизнью: здесь немного университетских аудиторий, необременительный намек на занятия, домашние задания, рефераты, сессии» (Ганжара, 2011).

В большинстве фильмов образ жизни студентов «представлен гедонистическими образцами поведения и различными формами экстремизма как наилучшего способа самореализации» (Васенин, Кухтевич, 2011: 150). К примеру, в сериале «Тронутые» (2005) персонажи выражают себя, устраивая ложное публичное самосожжение, в «Студентах» (2005) главный персонаж, чтобы попасть на телепередачу, окрашивает свои волосы в красный цвет, в «Веселой компании» (2003) предприимчивые студенты крадут у криминального авторитета яйцо Фаберже и т.п.

Одна из общих черт, присущих российским фильмам студенческой тематики, вышедшим на экраны в XXI веке, - отчужденность в отношениях между родителями и их детьми-студентами. Уже в ленте «Займемся любовью» (2002) была прервана «священная связь поколений», а «полное отсутствие таких важных для нашего менталитета общественно-нравственных понятий, как "родители", "семья", "дом", озадачивает» (Гусятинский, 2002). В телесериалах встречаются эпизоды, где студенты стесняются собственных родителей (Алла из «Универа», 2008-2011), преувеличивают их социальное и материальное положение (Владимир Квакуша из «Студентов», 2005), признаются в ненависти к ним (Алексей Сырников из «Кремлевских курсантов», 2009-2010).

Таки образом, в «российском кинематографе о молодежи стали преобладать ценности гедонизма, ориентированные сначала на отрицание культуры взрослого поколения с его активистскими ценностями, а позже, в современном периоде, на формирование коммерчески успешного имиджа молодости как бренда» (Ятина, Калинина, 2011: 175). Показательно, что чем ярче и самостоятельнее этот «бренд», тем меньше он связан не только с родительской опекой, но и вообще с культурными и историческими традициями. Между тем, согласно закономерностям психологического развития человека в старшем юношеском возрасте формируются нравственные, эстетические ценности и философское отношение к жизни, которые лежат в основе мировоззрения личности. Но вместо поисков себя современное студенчество характеризуется в кинематографе «беззаботностью, раскованностью, бесцельностью, независимостью от каких-либо обязательств» (Ятина, Калинина, 2011: 175).

Очевидно, что в XXI веке авторов российских фильмов студенческой тематики не интересуют проблемы поиска молодежью собственной идентичности. Как результат, студенты на экране не формулируют каких-либо серьезных жизненных целей, не задаются вопросами о моральном смысле собственных поступков и т.п.; то есть не занимаются тем, благодаря чему происходит развитие личности. Единственное чем они пытаются выразить собственную индивидуальность - внешний вид, а их самолюбие лишь только множит их пороки: безудержный гедонизм, ложь, зависть и др. Разумеется, это резко контрастирует с тем, какой молодежь представала, к примеру, в советских фильмах «оттепельного» периода («Мне двадцать лет», «Коллеги» и др.).

Создается ощущение, что киноперсонажи современных студентов оказались в пустом пространстве. С одной стороны, у них очень слабая, практически потерянная связь с родителями, с другой - отсутствует процесс поиска и становления их идентичности. Единственное, что наполняет их жизнь - влечение к противоположенному полу, стремление к развлечениям, материальным благам и социальному статусу.

В итоге, формируемый современным кино о студентах «бренд» - «отвязная молодежь» - сделал персонажей студенческих сериалов очень похожими друг на друга и взаимозаменяемыми. Например, в «Универе» сюжет возникает «как бы "на пустом месте", 
из ничего, вне конкретного времени и пространства. Сюжет должен повторяться и достраиваться (исчезает персонаж или часть его функций, к примеру, Гошан уходит в армию - на его месте должен появиться персонаж подобного типа (Майкл), вместо одного неудачного сына олигарха появляется другой (Антон)» (Ганжара, 2011). Много общего можно найти в другом сериале «Филфак», который если и отличается от «Универа», «то сугубо косметически. Да, декорации уже не три картонные стены, да, картинка побогаче и, да, саундтрек помоднее, но в целом схемы сериалов похожи - и Лена Александры Бортич не так уж далеко ушла от Аллочки "Пипец" из "Универа"» (Хохлов, 2017).

Что же остается в сухом остатке? То есть на чем строятся образы и события в современных фильмах студенческой тематики? Ответ достаточно прост - «параметры конфликтообразования строятся только по одному принципу - неподготовленность, экспромт, непредсказуемость, провокация» (Ганжара, 2011). А зритель уже «не шарахается при виде постельной сцены... Сегодня подглядывать не запрещено, значит - разрешено» (Гусятинский, 2002).

Сложившаяся ситуация позволяет согласиться с тем, что «что российское телевидение в развитии уже несколько застопорилось - зрителя не пытаются завлечь чем-то новым и необычным, ему подают снова и снова именно то, что хватается, и неважно с какой гримасой эти продукты поглощаются» (Голубев, 2017).

\section{4. Результаты исследования}

Герменевтический анализ игровых фильмов XXI века студенческой тематики

Место действия, исторический, религиозный, культурный, политический, идеологический контекст

Особенности исторического периода создания медиатекстов, условия рынка, которые способствовали замыслу, процессу создания медиатекстов, степень влияния событий того времени на медиатексты.

B XXI веке в новейшей истории России произошли значительные политические и социальные изменения. Благодаря росту мировых цен на нефть экономическая ситуация в России стала улучшаться, уже к 2008 году был накоплен значительный золотовалютный резерв и внешний долг оставался небольшим, что сказывалось на росте самостоятельности страны во внешней политике и улучшении благосостояния населения. Однако в 2008-2009 годах случился мировой финансовый кризис, который негативно сказался на состоянии российской экономики. После присоединения Крыма к России (16 марта 2014) против нее были введены экономические санкции со стороны США и ЕС. Санкции и резкое падение мировых цен на нефть привели к ухудшению экономической ситуации в РФ. В результате «в первой половине 2015 г. оборот розничной торговли упал на 8,1 \%. Это стало самым резким падением с начала 1990-х гг. В октябре 2015 г. средняя реальная зарплата в России сократилась на 10,9 \%» (Заец, 2017: 35).

Политические события XXI века практически не затронули российские фильмы на тему вуза. Зато на них существенно отразилось отсутствие цензуры. В фильмах студенческой тематики, снятых в XXI веке содержится значительное количество непристойных эпизодов, где, в частности, персонажи используют весьма грубую лексику. В мае 2014 года президентом РФ был подписан закон, запрещающий использовать «нецензурную лексику в теле- и радиоэфире и кинопрокате», после чего мат в фильмах о школе и вузе, разумеется, исчез, зато количество вульгарных, фамильярных и скабрезных выражений в них только увеличилось.

Как знание реальных исторических событий конкретного периода помогает пониманию данных медиатекстов.

При всем том в современных фильмах на студенческую тему отражены некоторые реальные историко-культурные тенденции: «коммерциализация российской общественной жизни..., исчезновение института воспитания..., утверждение индивидуализма, прагматизм, стремления к материальному достатку..., а также снижение уровня личной культуры студентов» (Васенин, Кухтевич, 2011: 150). Заметная дифференциация в материальном положении современной молодежи также отразилась на экране: персонажи живут не только в общежитии, но и на чердаках, в роскошных квартирах и особняках, ездят на автобусах и на дорогих автомобилях, живут впроголодь и ужинают в шикарных ресторанах. 
Другой феномен - коммерциализация, отразившаяся на всех сторонах жизни. Прежде всего в российских фильмах на тему вуза бросается в глаза то, что многие вещи перестали называть своими именами: если в советском кино взятка была преступлением и изображалась на экране как явление, порочащее честь и достоинство персонажей, то в современных лентах коррупция стала элементом «делового» общения студентов и преподавателей, а большинство персонажей воспринимает это как обыденную норму.

Равнодушие к моральным проблемам также стало привычным для фильмов о студенчестве, традиционные для советского кино «вечные» ценности (верность, самопожертвование, любовь, трудолюбие) остались в прошлом. Культ материальных ценностей, плотное информационное пространство убили экранную романтику - в фильмах о студентах почти нет сюжетных линий, рассказывающих о развитии настоящей любви, хотя сексуальных сцен предостаточно. Пожалуй, только в «Первокурснице» (2016) история любви имеет серьезное значение для сюжета.

Примеры исторических ссылок в медиатекстах

В России XXI века было снято более двух десятков фильмов, в которых главными действующими лицами были студенты. Большинство этих картин достаточно однообразно отражает современную действительность. Однако особый колорит и художественное качество появляются в работах авторов, взявших за основу различные периоды советского прошлого. В. Тодоровский в «Стилягах» (2008) воссоздал события 1950-х годов, авторы «Московских окон» (2001) повествовали об оттепели 1960-х годов, К. Шахназаров в «Исчезнувшей империи» (2007) делился воспоминаниями о своей студенческой молодости 1970-х, а в фильме «Овечка Долли была злая и рано умерла» (2014) авторы рассказали уже о студентах 1980-х.

Во все этих ретрофильмах есть исторические ссылки. Например, в «Стилягах» (2008) показана борьба комсомольских отрядов, так называемых «бригад добровольного содействия милиции» со стилягами - молодежью, ориентированную на западную моду и музыку. В. Тодоровский создал мюзикл, демифологизирующий атмосферу послесталинских 1950-х годов - взрослые и юные персонажи, осуждающие стиляг, выглядят гротескно и комично, а отцы главных героев - Мэлса и Фреда - относятся к ним снисходительно и даже поддерживают.

В «Московских окнах» (2001) получила отражение либерализация политической и общественной жизни 1960-х годов. В фильме есть эпизоды не только циничного отношения молодежи к коммунистическим лозунгам и идеалам, но и целая сюжетная линия, вскрывающая пороки советской системы. Возглавляющий комсомол института Леонид Терехов, сын второго секретаря московского горкома КПСС, не желает вступать в партию и руководит действиями своего друга, перепродающего импортную одежду.

В «Исчезнувшей империи» (2007) К. Шахназаров поделился своими эмоциональными воспоминаниями о брежневских временах 1970-х, когда советские студенты считали шиком недоступные для многих билеты в Театр на Таганке или диски The Rolling Stones. Здесь «герои переживают первые соблазны и первую любовь, первое предательство и первые разочарования. Это фильм и радостный и горький, и ни в коем случае не ностальгический. Радость от встречи с юностью, какой теперь не бывает» (Кичин, 2014).

Еще одну любопытную историческую деталь можно найти в фильме «Овечка Долли была злая и рано умерла» (2014), где главный герой - студент Никита - фантастическим образом из России XXI века попадает в советское прошлое, в 1980-е годы. Кроме мобильного телефона у него с собой оказались доллары, которые (к его сильному удивлению) грозили ему теперь статьей УК № 88, предусматривающей лишение советских граждан свободы за любые операции с валютой.

Социокультурный, идеологический, мировоззренческий, религиозный контекст

Идеология, мировоззрение авторов медиатекстов в социокультурном контексте

Авторы многих российских фильмов и сериалов о студентах, снятых в XXI веке, практически пропагандировали беспорядочные интимные отношения студентов, коррупцию с вузовской среде, гедонистический образ жизни. Такое заключение можно сделать потому, что в фильмах крайне редко осуждаются пороки, а о нравственных проблемах речь вообще не идет. Сюжеты только нескольких сериалов построены на наивном торжестве справедливости («Веселая компания», 2003; «Студенты», 2005-2006; 
«Кремлевские курсанты», 2009-2010; «Первокурсница», 2016). Видимо авторы большинства фильмов и сериалов на студенческую тему следовали правилу: никакой мрачности, никакого уныния и как можно больше необычных и комичных ситуаций. В результате получалась наивная, фальшивая и гламурная реальность.

Стремясь удивить зрителя, авторы придумывали вычурные и пошлые сцены. Например, в эпизоде интимной связи из фильма «Детям до 16...» (2010) «герои мажут свои тела гуашью, брезгливо трутся друг о друга, но так как режиссеру с оператором нужна лишь эффектная картинка, зритель видит вместо красоты манерность исполнения» (Ющенко, 2010).

Мировоззрение людей студенческого мира, изображенного в медиатекстах

Мировоззрение персонажей фильмов на тему вуза, снятых после 2000-го года, оптимистично и ориентировано на развлечения. В немногих фильмах действительную тягу к знаниям обозначают всего один-два персонажа (которые, как правило, становятся для авторов объектами издевки). Среди студентов практически не встречаются персонажи, испытывающие муки совести, размышляющие в одиночестве о «смысле жизни». В большинстве из них студенты шутят над своими соседями по общежитию или преподавателями, нередко проявляя агрессию или желание к доминированию. Для привлечения внимания противоположенного пола персонажи стараются выглядеть и вести себя как можно ярче, в их диалогах постоянно возникает тема интимных отношений.

Пожалуй, можно назвать два фильма, в которых главные герои получают нравственный урок: «Кремлевские курсанты» (2009-2010) и «Овечка Долли была злая и рано умерла» (2014). Если в «...курсантах» студенты эпизодически попадают в ситуации, где им приходится просить прощение за свои ошибки или убеждаться в искренности друзей, то в «Овечке Долли...» весь сюжет построен на том, что герой меняет свое высокомерное отношение к собственным родителям. В фильме рассказывается о студенте, которого «судьба забрасывает в прошлое, чтобы он понял, что его отец - мировой мужик, и чтобы он осознал, какой крепкой и веселой была дружба во времена, когда молодые люди не жили в компьютерах и сотовых телефонах. Герой "Долли" не исправляет былое - он усваивает его урок и начинает иначе смотреть на некоторые вещи и на некоторых людей» (Иванов, 2015).

Структура и приемы повествования в данных медиатекстах

Схематично структуру, сюжет, репрезентативность, этику, особенности жанровой модификации, иконографии, характеров персонажей можно представить следующим образом:

- место и время действия медиатекстов, характерная для данньх медиатекстов обстановка, предметы быта: XXI век, комнаты и коридоры студенческих общежитий, университетские коридоры и аудитории, полузаброшенные чердачные помещения («Пер-рр-вокурсница», 2002; «Детям до 16...», 2010), роскошные квартиры и особняки («Веселая компания», 2003; «Универ», 2008-2011), казармы («Кремлевские курсанты», 2009-2010). В начале XXI века быт жильцов большинства фильмов о студентах был довольно скромен, но ситуация изменилась в 2010-х годах - в комнатах и квартирах студентов появилась дорогостоящая техника и мебель.

- жанровые модификации: преобладают жанры комедии и мелодрамы.

- (стереотипные) приемы изображения действительности: в большинстве ситуаций студенты улыбаются и шутят, болтают о текущих делах. Сцены сняты в основном короткими планами в эксцентричной манере.

Типология персонажей (черты характера, одежда, телосложение, лексика, мимика, жесты персонажей, присутствие или отсутствие стереотипной манеры репрезентации персонажей в даннъх медиатекстах):

- возраст персонажей: возраст студентов - 18-22 года. Возраст других персонажей: молодые преподаватели 30-35 лет, взрослые преподаватели 45-60 лет, а также родители 4555 лет и дедушки, бабушки 65-75 лет.

- уровень образования: у студентов соответствует курсу обучения. У других персонажей различные варианты.

- социальное положение, профессия: материальное положение студентов заметно дифференцированно. Некоторые из них из рабочих семей с небольшим достатком, другие из семей состоятельных предпринимателей и чиновников и т.п. 
- семейное положение: студенты не состоят в браке, либо вступают в семейный союз. Преподаватели часто не женаты и ищут интимных отношений с коллегами или со студентами.

- внешний вид, одежда, телосложение персонажей, черты характера, лексика. Как правило, персонажи одеты нескромно и даже вызывающе. Студентки носят короткие юбки, шорты, порванные джинсы. И студенты, и преподаватели в диалогах используют грубую лексику, не редко проявляют фамильярность в отношении друг друга. Педагоги чаще выглядят комично и не соответствуют образу интеллектуалов.

Существенное изменение в жизни персонажей медиатекстов:

Bapuaнm № 1: поступившие в институт студенты попадают в общежитие, где студенты старших курсов ущемляют их в правах («Студенты», 2005, 2006; «Кремлевские курсанты», 2009-2010).

Вариант № 2: студент или студентка стремиться познакомиться с девушкой/парнем, другие ему/ей мешают или помогают («Займемся любовью», 2002; «Универ», 2008-2011; «Филфак», 2017).

Вариант № 3: студенты невольно становятся участниками проблемной ситуации, в которой им приходится восстанавливать справедливость («Веселая компания», 2003; «Тронутые», 2005).

Решение проблемы:

Вариант № 1: студенты-первокурсники приходят на помощь друг другу, объединяясь и отстаивая свои права. В дальнейшем они добиваются уважения.

Вариант № 2: преодолевая череду препятствий, студент/студентка обретают «вторую половинку».

Вариант № 3: студенты приходят на помощь другим персонажам (помогают вернуть украденные вещи, защищают слабых, наставляют или обучают каким-либо навыкам других персонажей и т.п.), восстанавливая справедливость.

\section{5. Выводы}

Большинство фильмов о студентах XXI века имеет свои отличительные особенности. Например, количество положительных персонажей, отличающихся выдающимися умственными способностями и высоконравственными качествами, стало столь незначительным, что в некоторых картинах их и вовсе нет. Однако большинству персонажей присущи негативные черты: наивное понимание реальной действительности, недальновидность, стремление к беспорядочной интимной близости и развлечениям.

По результатам проведенного нами исследования можно сделать вывод, что в российских фильмах на тему вуза, снятых в XXI веке:

- персонажи студенческих сериалов очень похожи друг на друга и взаимозаменяемы, хотя дифференциация их материального положения заявлена вполне отчетливо;

- персонажи-студенты равнодушны к моральным проблемам (традиционные для советского кино «вечные» ценности: верность, самопожертвование, любовь, трудолюбие остались в прошлом); не формулируют каких-либо серьезных жизненных целей, зачастую не задаются вопросами о смысле и последствиях собственных поступков и т.п.;

- в отношениях с преподавателями студенты нередко проявляют фамильярность, панибратство; между преподавателями и студентами возникают также коррупционные отношения; студенты часто отчуждены от своих родителей.

- в фильмах на студенческую тему, снятых, как правило, в комедийном жанре, содержатся эпизоды сексуального характера, грубая лексика.

\section{6. Благодарности}

Статья написана в рамках исследования при финансовой поддержке гранта Российского научного фонда (РНФ). Проект № 17-18-01001 «Школа и вуз в зеркале советских, российских и западных аудиовизуальных медиатекстов», выполняемый в Ростовском государственном экономическом университете.

\section{Литература}

Бутрин, 2017 - Бутрин Д. Играем в оттепель // Искусство кино. 2017. № 4. 
http://kinoart.ru/archive/2017/o4/igraem-v-ottepel

Бэзэлгэт, 1995 - Бэзэлгэт К. Ключевые аспекты медиаобразования. М.: Изд-во Ассоциации деятелей кинообразования, 1995. $51 \mathrm{c}$.

Васенин, Кухтевич, 2011 - Васенин И.В., Кухтевич Т.Н. Российское студенчество: вчера и сегодня // Социология образования. 2011. № 10. С.147-152.

Ганжара, 2011 - Ганжара О. Миф об Универе. Сериал «Универ» // Искусство кино. 2011. № 11. http://kinoart.ru/archive/2011/11/n11-article7

Голубев, 2017 - Голубев Д. «Филфак»: Тихий гуманитарный ужас // Новый взгляд. 2017. http://www.newlookmedia.ru/?p=53076

Гусятинский, 2002 - Гусятинский Е. Век невинности остался в прошлом // Искусство кино. 2002. № 6. http://kinoart.ru/archive/2002/o6/n6-article13

Заец, 2017 - Заец С.В. История России. XXI век. Хроника основных событий. Ярославль. ЯрГУ. 2017. 48 с.

Иванов, 2015 - Иванов Б. Друг из будущего // Фильм.ру. 2015. https://www.film.ru/articles/drug-iz-buduschego

Кичин, 2014 - Кичин В.С. Атлантида как она есть // Российская газета. 2014. № 6361. https://rg.ru/2014/o4/17/d2f-imper-poln.html

Нефедов, 2010 - Нефедов E. Детям до 16... // World Art. 2010. 29 сентября. http://www.world-art.ru/cinema/cinema.php?id=26443

Хохлов, 2017 - Хохлов Б. Реальные ботаны // Фильм.py. 2017. https://www.film.ru/articles/realnye-botany

Эко, 2005 - Эко У. Роль читателя. Исследования по семиотике текста. СПб: Симпозиум, 2005. 502 c.

Ющенко, 2010 - Ющенко A. «Правила секса» // Filmz.ru. 2010. 20 сентября. http://www.filmz.ru/pub/7/20584_1.htm

Ятина, Калинина, 2011 - Ятина Л.И., Калинина Т.С. Изображение стиля жизни молодежи в российском кинематографе: трансформация практик в обществе потребления // Журнал социологии и социальной антропологии. 2011. № 5. С. 168-181.

Silverblatt, 2001 - Silverblatt, A. Media Literacy. Westport, Connecticut - London: Praeger, 2001, 449 p.

\section{References}

Bezelget, 1995 - Bezelget K. (1995). Klyuchevye aspekty mediaobrazovaniya [Key Aspects of Media Education]. M.: Izd-vo Assotsiatsii deyatelei kinoobrazovaniya, $51 \mathrm{p}$.

Butrin, 2017 - Butrin D. (2017). Igraem v ottepel' [We are playing in a thaw]. Iskusstvo kino. № 4. http://kinoart.ru/archive/2017/o4/igraem-v-ottepel

Eko, 2005 - Eko U. (2005). Rol' chitatelya. Issledovaniya po semiotike teksta [The role of the reader. Explorations in the semiotics of texts]. SPb: Simpozium, $502 \mathrm{p}$.

Ganzhara, 2011 - Ganzhara O. (2011). Mif ob Univere. Serial «Univer» [Myth of the Univer. The series "Univer"]. Iskusstvo kino. № 11. URL: http://kinoart.ru/archive/2011/11/n11-article7

Golubev, 2017 - Golubev D. (2017). «Filfak»: Tikhii gumanitarnyi uzhas ["Filfak": Quiet humanitarian horror]. Novyi vzglyad. URL: http://www.newlookmedia.ru/?p=53076

Gusyatinskii, 2002 - Gusyatinskii E. (2002). Vek nevinnosti ostalsya v proshlom [The Age of Innocence Remained in the Past]. Iskusstvo kino. № 6. URL: http://kinoart.ru/archive/2002/06/ n6-article13

Ivanov, 2015 - Ivanov B. (2015). Drug iz budushchego [Friend from the future]. Fil'm.ru. URL: https://www.film.ru/articles/drug-iz-buduschego

Khokhlov, 2017 - Khokhlov B. (2017). Real'nye botany [Real botanists]. Fil'm.ru. URL: https://www.film.ru/articles/realnye-botany

Kichin, 2014 - Kichin V.S. (2014). Atlantida kak ona est' [Atlantis as it is]. Rossiiskaya gazeta. № 6361. URL: https://rg.ru/2014/o4/17/d2f-imper-poln.html

Nefedov, 2010 - Nefedov E. (2010). Detyam do 16... [Children under 16...]. World Art. 29 sentyabrya. URL: http://www.world-art.ru/cinema/cinema.php?id=26443

Vasenin, Kukhtevich, 2011 - Vasenin I.V., Kukhtevich T.N. (2011). Rossiiskoe studenchestvo: vchera i segodnya [Russian students: yesterday and today]. Sotsiologiya obrazovaniya. № 10. pp. 147-152. 
Yatina, Kalinina, 2011 - Yatina L.I., Kalinina T.S. (2011). Izobrazhenie stilya zhizni molodezhi v rossiiskom kinematografe: transformatsiya praktik v obshchestve potrebleniya [Image of the youth lifestyle in the Russian cinema: the transformation of practices in the consumer society]. Zhurnal sotsiologii i sotsial'noi antropologii. № 5. pp. 168-181.

Yushchenko, 2010 - Yushchenko A. (2010). «Pravila seksa» ["Rules of sex"]. Filmz.ru. 20 sentyabrya. URL: http://www.filmz.ru/pub/7/20584_1.htm

Zaets, 2017 - Zaets S.V. (2017). Istoriya Rossii. XXI vek. Khronika osnovnykh sobytii [Russian history. XXI Century. Chronicle of the main events]. Yaroslavl'. YarGU. 48 p.

Silverblatt, 2001 - Silverblatt, A. Media Literacy. Westport, Connecticut - London: Praeger, 2001, 449 p.

\section{Герменевтический анализ российских игровых фильмов XXI века на тему вуза}

\section{Роман Сальный а}

a Ростовский государственный экономический университет, Российская Федерация

Аннотация. В статье проводится герменевтический анализ российских игровых фильмов на тему вуза, снятых в XXI веке, анализируются мнения экспертов о состоянии современного отечественного кино о молодежи, идеологический и социокультурный контекст 2000-2017 годов. По результатам проведенного исследования можно сделать вывод, что в российских фильмах на тему вуза, снятых в XXI веке: персонажи студенческих сериалов очень похожи друг на друга и взаимозаменяемы, хотя дифференциация их материального положения заявлена вполне отчетливо; персонажи-студенты равнодушны к моральным проблемам (традиционные для советского кино «вечные» ценности: верность, самопожертвование, любовь, трудолюбие остались в прошлом); не формулируют каких-либо серьезных жизненных целей, зачастую не задаются вопросами о смысле и последствиях собственных поступков и т.п., в отношениях с преподавателями студенты нередко проявляют фамильярность, панибратство; между преподавателями и студентами возникают также коррупционные отношения; студенты часто отчуждены от своих родителей. В фильмах на студенческую тему, снятых, как правило, в комедийном жанре, содержатся эпизоды сексуального характера, грубая лексика.

Ключевые слова: герменевтический анализ, фильм, сериал, Россия, студенты, преподаватели, вуз, университет, кинематограф.

\section{Приложение}

\section{Фильмография}

2001

Московские окна. Россия, 2оо1. Режиссер Александр Аравин. Сценаристы: Константин Наумочкин, Алексей Каранович, Игорь Осипов, Алексей Овчинников, Сергей Кобцев, Алексей Поярков, Владимир Неклюдов, Дмитрий Руковишников, Владимир Смирных. Актеры: Анна Арланова, Марина Могилевская, Игорь Бочкин, Елена Аминова, Ксения Алфёрова, Илья Древнов, Николай Чиндяйкин, Елена Финогеева, Игорь Петренко и др. Мелодрама.

Общага. Россия, 2оо1. Режиссер Борис Берзнер. Актеры: Владимир Гусев (II), Наталья Карпунина, Юрий Круглов, Максим Лагашкин и др. Комедия.

2002

Займемся любовью. Россия, 2оо2. Режиссер Денис Евстигнеев. Сценарист Ариф Алиев. Актеры: Кирилл Малов, Евгений Цыганов, Ульяна Лукина, Андрей Новиков, Иван Кокорин и др. Драма. 
Пер-р-р-вокурсница. Россия, 2002. Режиссер и сценарист Юрий Рогозин. Актеры: Мария Шалаева, Дмитрий Шевченко, Юрий Данильченко и др. Комедия.

2003

Весёлая компания. Россия, 2о03. Режиссер Владимир Тихий. Сценаристы: Олег Зима, Георгий Конн, Александра Смилянская, Армен Ватьян. Актеры: Олег Мосалев, Евгений Сиротин, Артём Мазунов, Екатерина Лыкова, Эммануил Виторган, Александр Лыков и др. Комедия.

\section{5}

Студенты-1 Россия, 2005. Режиссер Ольга Перуновская. Сценаристы: Вячеслав Дусмухаметов, Виталий Коломиец и др. Актеры: Евгений Кулаков, Сергей Рудзевич, Алексей Янин, Дарья Лузина, Юрий Кузнецов, Владимир Стержаков, Дмитрий Марьянов и др. Комедия.

Тронутые. Россия, 2о05. Режиссер Анатолий Газиев. Сценаристы: Анатолий Газиев, Дмитрий Заболотских. Актеры: Дмитрий Паламарчук, Валентин Захаров, Виталий Исаков, Сергей Барковский и др. Комедия.

\section{6}

Студенты-2. Россия, 2оо6. Режиссер Ольга Перуновская. Сценаристы: Роман Романов, Алекс Легат, Василий Иванов и др. Актеры: Ивар Калныньш, Владимир Стержаков, Михаил Мамаев и др. Комедия.

Студенты International. Россия, 2о06. Режиссер Ольга Перуновская. Сценаристы: Виталий Шляппо, Вячеслав Дусмухаметов, Алексей Троцюк и др. Актеры: Евгений Кулаков, Евгения Волкова, Алексей Лонгин, Юлия Зимина, Александр Пальчиков, Валерий Золотухин, Александр Панкратов-Чёрный, Владимир Стержаков, Эвелина Блёданс и др. Комедия.

\section{7}

Исчезнувшая империя (Любовь в СССР). Россия, 2007. Режиссер Карен Шахназаров. Сценаристы: Сергей Рокотов, Евгений Никишов. Актеры: Александр Ляпин, Лидия Милюзина, Егор Барановский, Иван Купреенко, Армен Джигарханян, Ольга Тумайкина, Владимир Ильин и др. Драма.

\section{8}

Стиляги. Россия, 20о8. Режиссер Валерий Тодоровский. Сценарист Юрий Коротков. Актеры: Антон Шагин, Оксана Акиньшина, Евгения Брик, Максим Матвеев, Екатерина Вилкова, Сергей Гармаш, Олег Янковский, Ирина Розанова, Леонид Ярмольник, Алексей Горбунов и др. Музыкальная драма.

2010

Детям до 16... Россия, 2010. Режиссер Андрей Кавун. Актеры: Лянка Грыу, Анна Старшенбаум, Павел Прилучный, Дмитрий Кубасов, Родион Долгирев, Алексей Горбунов, Ирина Мерцалова, Алексей Шевченков, Ольга Хохлова, Валерий Тодоровский и др. Мелодрама.

Кремлёвские курсанты. Россия, 2009-2о10. Режиссеры: Валентин Козловский, Дмитрий Чирков. Сценаристы: Леонид Купридо, Андрей Чивурин, Александр Кушнаренко, Валентин Иванов и др. Актеры: Денис Береснев, Павел Бессонов, Аристарх Венес и др. Драма.

\section{1}

Универ. Россия, 2008-2011. Режиссеры: Пётр Точилин, Иван Китаев, Роман Самгин, Жанна Кадникова. Сценаристы: Вячеслав Дусмухаметов, Семён Слепаков, Илья Полежайкин, Максим Пешков и др. Актеры: Андрей Гайдулян, Валентина Рубцова, Виталий Гогунский, Мария Кожевникова и др. Комедия. 
2013

Универ: день открытых дверей. Россия, 2013. Режиссер Роман Новиков. Актеры: Анна Кузина, Роман Петренко, Александр Дулерайн, Арарат Кещян, Илья Полежайкин, Юлия Галиченко и др. Комедия.

2014

Анжелика. Россия, 2014. Режиссеры: Радда Новикова, Антон Федотов, Валерия Ивановская, Антон Маслов. Сценаристы: Ирина Журавлёва, Денис Остапчук, Денис Ворочай и др. Актеры: Анжелика Каширина, Ксения Теплова, Мария Баева, Любовь Толкалина и др. Комедия.

Овечка Долли была злая и рано умерла. Россия, 2014. Режиссер Алексей Пиманов. Сценаристы: Галина Сальгарелли, Елена Серова, Алексей Пиманов. Актеры: Данила Шевченко, Юлия Савичева, Виктор Сухоруков и др. Фантастика.

\section{6}

Первокурсница. Россия, 2016. Режиссер Валерия Ивановская. Сценаристы: Евгений Куратов, Вадим Фоминых. Актеры: Анна Тараторкина, Екатерина Симаходская, Алексей Анищенко, Аристарх Венес и др. Мелодрама.

Универ: новая общага. Россия, 2011-2016. Режиссеры: Рустам Мосафир, Константин Смирнов, Максим Зыков, Тимофей Шоталов. Сценаристы: Евгений Соболев, Антон Колбасов, Максим Вахитов, Юлия Галиченко, Илья Полежайкин и др. Актеры: Виталий Гогунский, Арарат Кещян, Станислав Ярушин, Анна Кузина, Настасья Самбурская, Анна Хилькевич и др. Комедия.

2017

Филфак. Россия, 2017. Режиссер Фёдор Стуков. Актеры: Денис Парамонов, Алексей Золотовицкий, Василий Поспелов, Ефим Шифрин, Александра Бортич, Алексей Литвиненко и др. Комедия. 